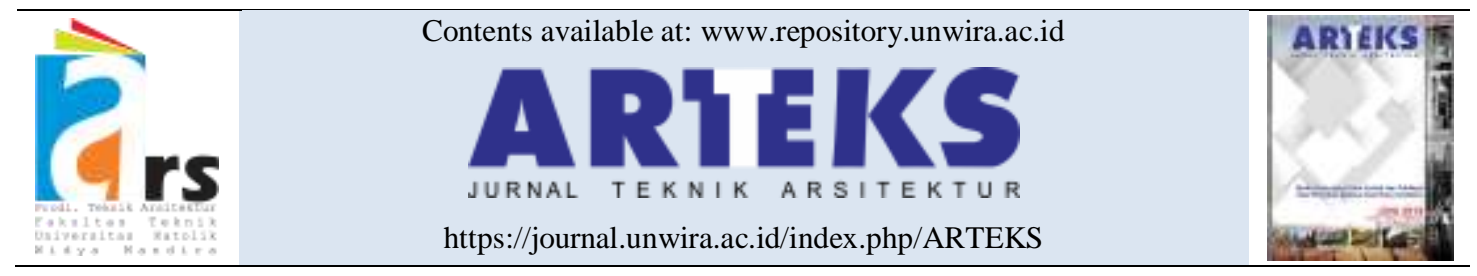

Research paper

doi: $10.30822 /$ arteks.v6i3.882

\title{
The persistence and spatial transformations of traditional Joglo house according to hamemayu hayuning bawana philosophy
}

\author{
Brigitta Michelle, Yohanes Djarot Purbadi* \\ Department of Architecture, Faculty of Engineering, Universitas Atma Jaya Yogyakarta \\ Jl. Babarsari 44, Sleman, Indonesia
}

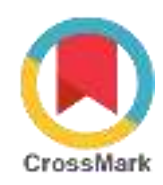

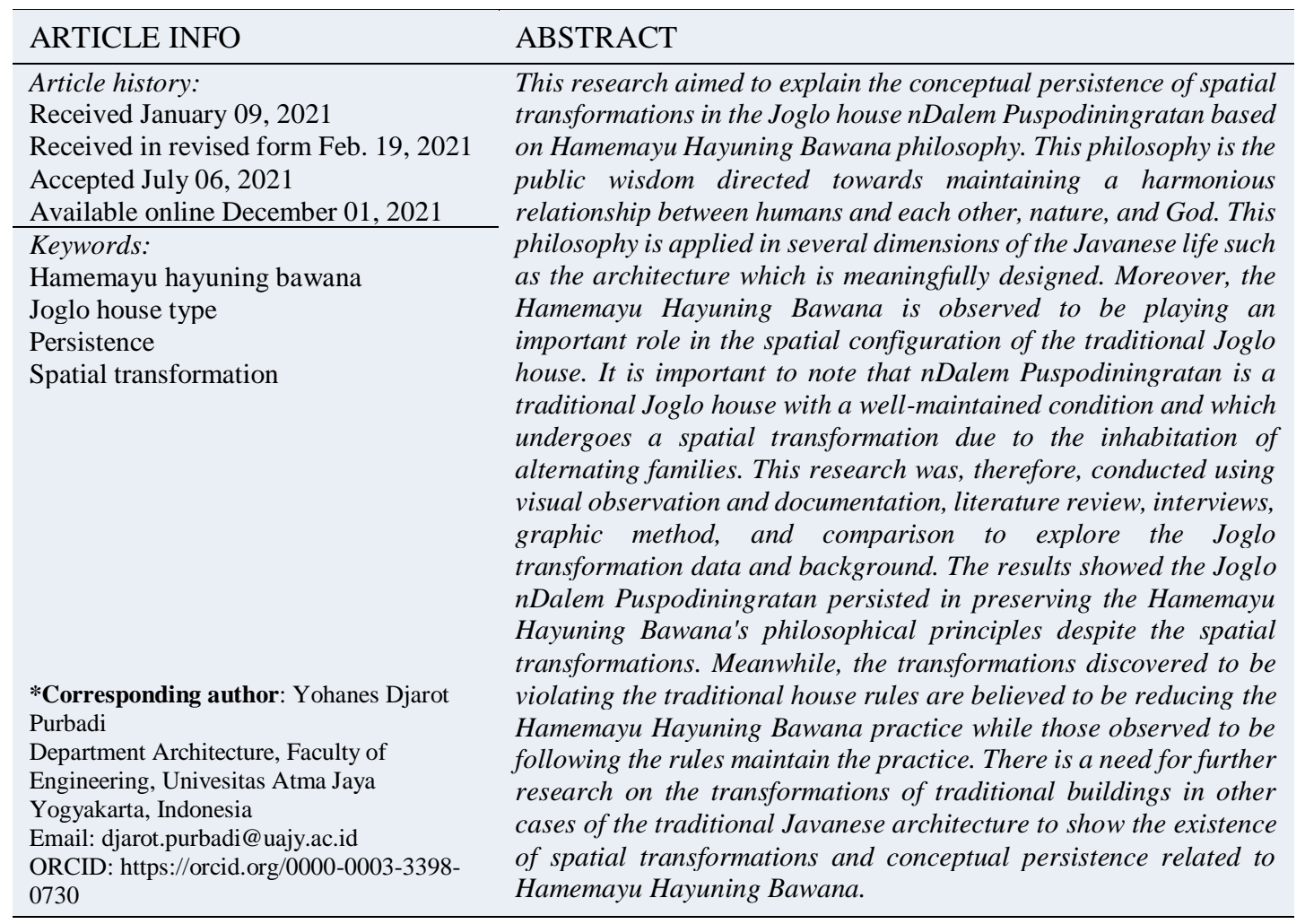

\section{Introduction}

Spatial transformations are not unusual in architecture. They exist in every kind of architecture, from small spaces to city areas. Moreover, the concept of "spatial" is defined as the element of space consisting of shape, size, shadow, pattern, and texture (Minnatika 2019). Its transformations form patterns according to some physical and non-physical influencing factors (Giyarsih 2010 and Jayanti 2012). These transformations can be in the form of an addition, subtraction, or change in the environment of activities (Mahendra and Pradoto 2016).

Persistence in architecture is also not a strange happenstance due to its existence in several scopes of architecture such as heritage buildings where it is most apparent. This is observed in the traditional Joglo house which is peculiar to Java, especially Central Java, (Kiswari 2019) where each part of the building has a Javanese name with deep philosophical meaning (Sari and Patria 2020). For example, Joglo means communicating with God both vertically and horizontally as well 
as with other realms and the environment (Subiyantoro 2011). Moreover, the traditional Joglo house has a noble philosophy which is known as the Hamemayu Hayuning Bawana.

This philosophy teaches humans to always live in harmony with each other, the environment, and God (Nugroho and Elviandri 2018). It is focused on building the welfare of the world and society both physically and mentally by prioritizing truth, virtue, and justice (Hariwijaya 2005). Its function is to beautify the world by maintaining harmony in its inherent relationships (Pangesti 2017).

Heritage buildings need to undergo several changes over time to fulfill the needs of the users and this requires deciding either to follow the traditional principles or implement more modern practices in the name of conservation. The second option, however, has the ability to introduce certain negative aspects to the building which require certain elements with specific cosmological and philosophical meanings to be sacrificed for the users' needs even though these meanings are the soul of the building (Siwalatri 2014; Susanta and Wiryawan 2016; Sastrosasmito 2020).

nDalem Puspodiningratan shown in figure 1 was studied to determine the way conservation can preserve or destroy the philosophy of a heritage building. This is a traditional Joglo house located in Yogyakarta City and constructed in line with the Hamemayu Hayuning Bawana philosophy. The relationships of the house with humans, nature, and God are, therefore, explored throughout the research.

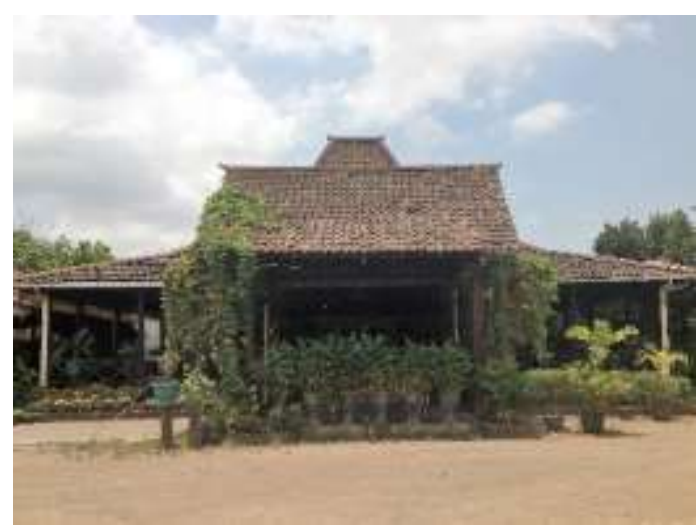

Figure 1. Front view of $n$ Dalem Puspodiningratan

The findings were compared with other studies to show this study's validity regarding spatial transformation in a traditional Joglo house.
It is important to note that the spatial transformations of two Joglo houses in Omah UGM and nDalem Purwodiningratan have been compared in a previous study (Pratama, Djalari, and Laksemi 2018) but their relation to Hamemayu Hayuning Bawana philosophy was not mentioned. Some others have focused on their aesthetic transformation (Utomo 2006), physical condition assessment (Kusuma and Cahyandari 2018), and Javanese aesthetics (Subiyantoro 2011). Moreover, previous research has also discovered spatial transformation in a peri-urban area of Malang (Mahendra and Pradoto 2016) and Surakarta (Jayanti 2012) as well as Kedungsepur Urban Corridor (Minnatika 2019). Some researchers also focused on Hamemayu Hayuning Bawana and its values (Wijaya, Lutfillah, and Mangoting 2015), implementation in rural development (Prijono 2015), and cultural perspective (Wagiran 2012). It was discovered that there is no research on Hamemayu Hayuning Bawana's sustainability in the spatial transformations of a traditional Joglo house. This research was, therefore, conducted to understand the ability of a renovation process to change the philosophy of certain spaces as well as to determine the kind of spatial transformation which has the ability to cause the change. The philosophy used in this case is the Hamemayu Hayuning Bawana.

\section{Method}

This research was conducted using the participant observation method. This requires the researcher to spend time observing a particular context (Bryman 1989). Moreover, interviews were conducted through descriptive observation to obtain a considerable amount of information (Spradley 1980). A semi-structured interviewing technique was also used to retrieve answers from the owners of the building. This involved asking specific and open-ended questions to obtain unpredictable answers (Gillham 2008).

The discussion aspect is inductive with the focus on specific problems which contains evidence and examples of facts and ends with a conclusion provided in the form of a general statement (Kurnia 2007). According to Shaw, the inductive research process analyzes data collected in the field and openly through interview analysis and field notes, uses focus analysis to compare 
and categorize emerging themes, deepens the analysis, present the result, and check the analysis's accuracy with informants while taking notes (Kurnia, 2010). Moreover, graphical analysis was applied through the buildings' representation in 2D and 3D (Brusaporci 2016). A comparative method was also used to analyze the findings on traditional Joglo configuration in literature by examining different combinations of results with textbook presentations (Ragin 2004).

Observations were made to obtain primary data through interviews with the house owner, taking photographs, and collecting spatial data such as the measurement of the house and drawing. General questions were also asked to determine the house's history while some specific questions were asked on its condition and physical changes. Moreover, interviews and field notes were analyzed using the graphical analysis and comparative method to determine the implications of spatial transformation. This was followed by focus analysis to compare the data with the three elements of Hamemayu Hayuning Bawana which are men's relationship with others, environment, and God. Further analysis was also conducted by comparing the findings with existing concepts published in books and journals. This was followed by the presentation of the final analysis on the spatial changes in the house to the owner for inventory.

\section{Result and discussion}

The analysis of the spatial transformation of nDalem Puspodiningratan based on Hamemayu Hayuning Bawana is discussed using three points associated with the philosophy which include the harmonious relationship of humans with others, their environment, and God.

1. The harmonious relationship between the people

Humans were observed to be maintaining harmonious relationships within the unchanged elements and spatial transformations of the house. This is indicated by the zoning of the main rooms which involved the placement of the pendapa in the very front of the house and constructed without walls as shown in figure 2 . The area is considered a semi-public zone due to the fact that it is usually used to entertain guests. It is, however, followed by the Dalem section which is enclosed with walls and considered a semi-private zone.

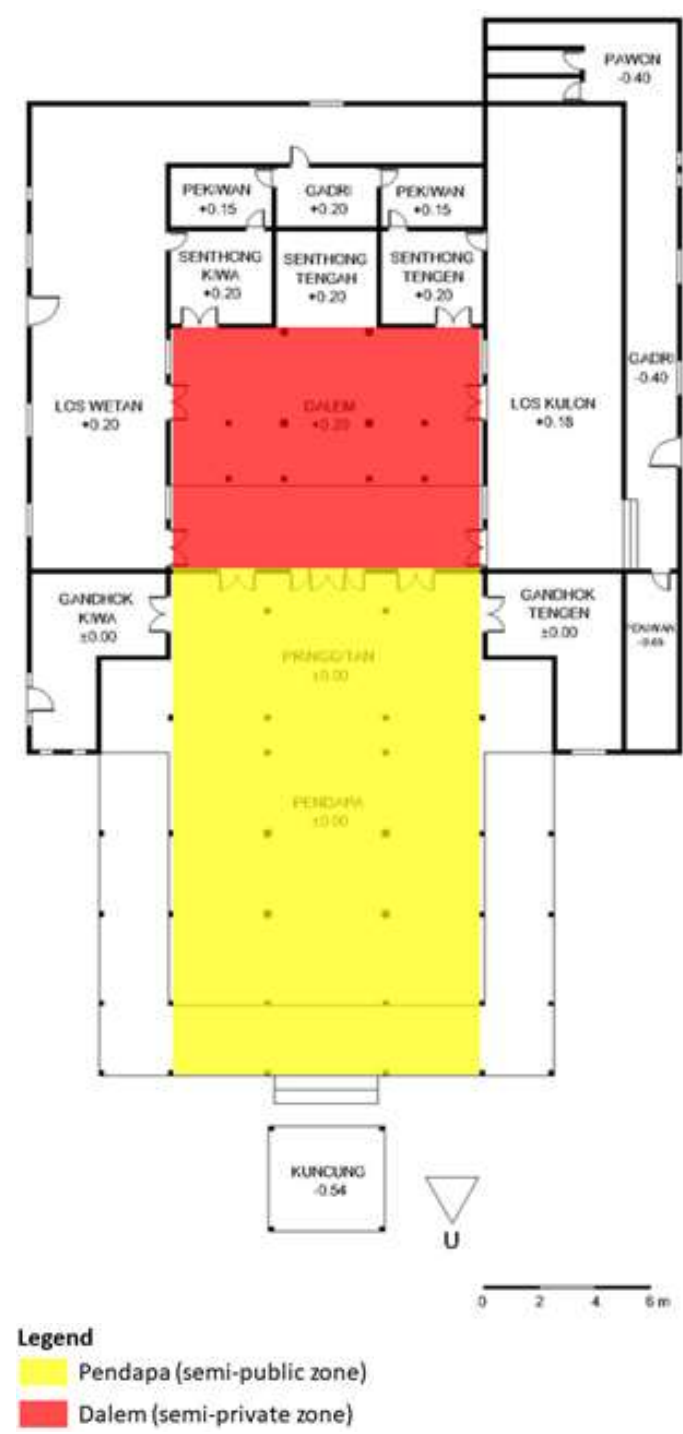

Figure 2. Zoning of unchanged house elements

The pendapa categorized into the semi-public zone in figure 2 has the ability to facilitate a harmonious relationship between the inhabitants and their guests. 


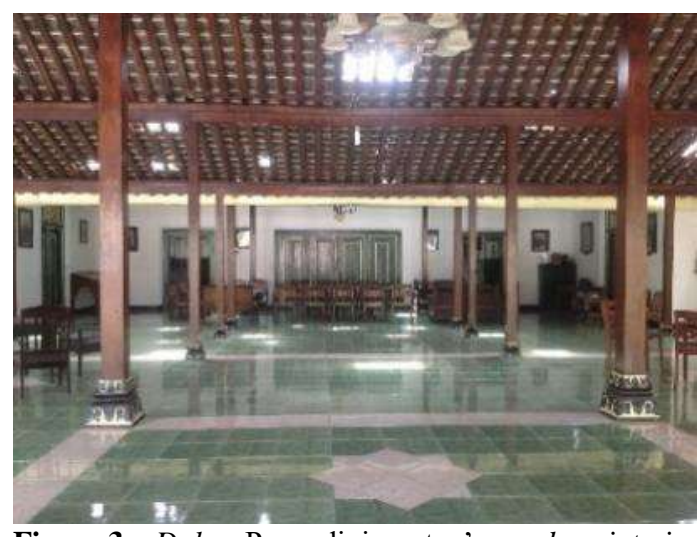

Figure 3. nDalem Puspodiningratan's pendapa interior

Pendapa is a building without walls but with four main pillars (saka guru) usually used for 'public' activities such as receiving guests. It is located at the very front part of the house to ensure it is visible from the outside and tends to be made impressive and prestigious (UNESCO 2007). Figure 3 also shows pendapa in nDalem Puspodiningratan is used to receive guests and for other social occasions and this means it functions according to the supposed intention and also provides a harmonious relationship among the humans.

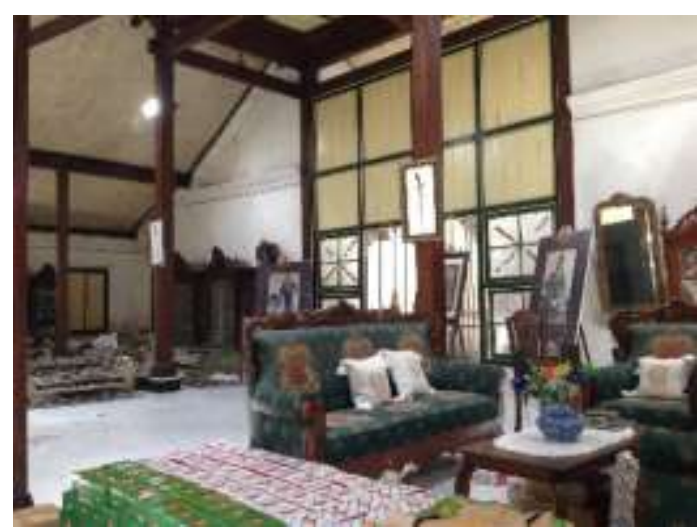

Figure 4. Dalem as a family room

Figure 4 shows the dalem in nDalem Puspodiningratan is used as a living room in line with the supposed intention. It is the main building which functions as the family room and is divided into two parts including the senthong and the living room (UNESCO 2007). Dalem is categorized into the semi-private zone and has the ability to facilitate harmonious relationships between the inhabitants.
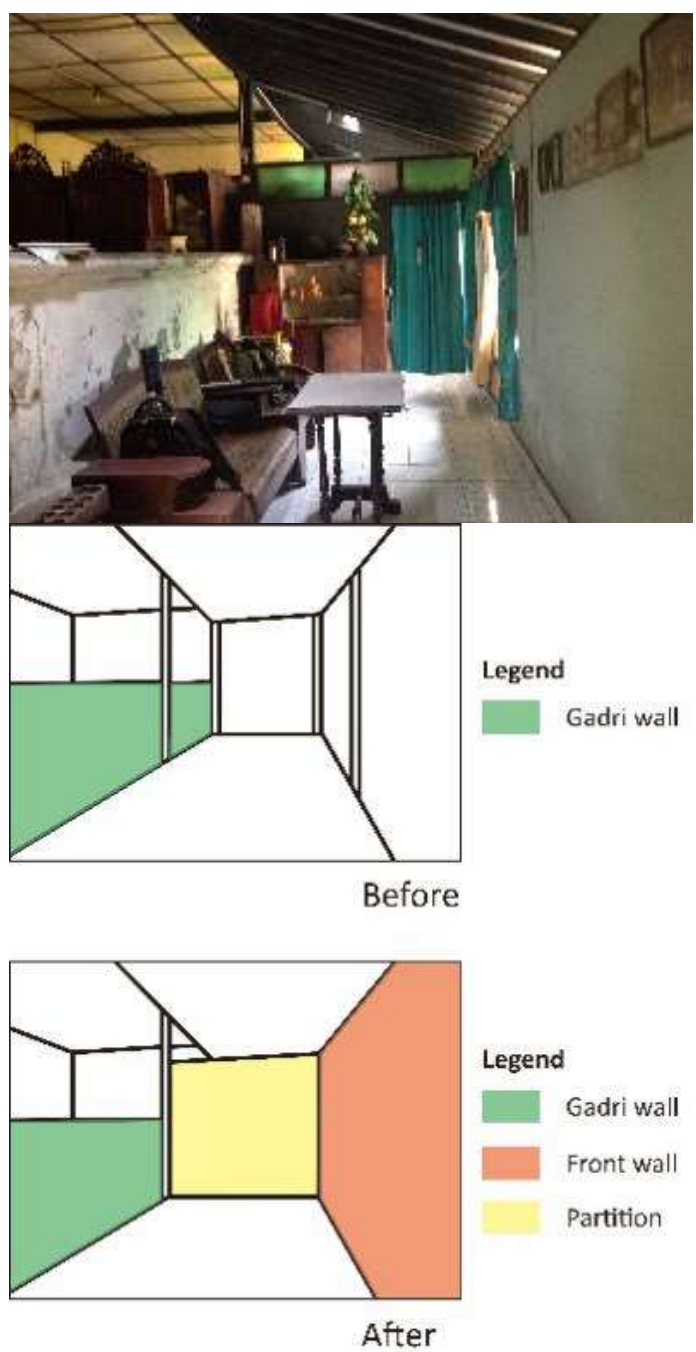

Figure 5. Changes in Gadri

The elements undergoing spatial transformations were also observed to be maintaining the required balance. For example, Gadri was a terrace without a front wall as indicated in the original border presented in figure 5 . 


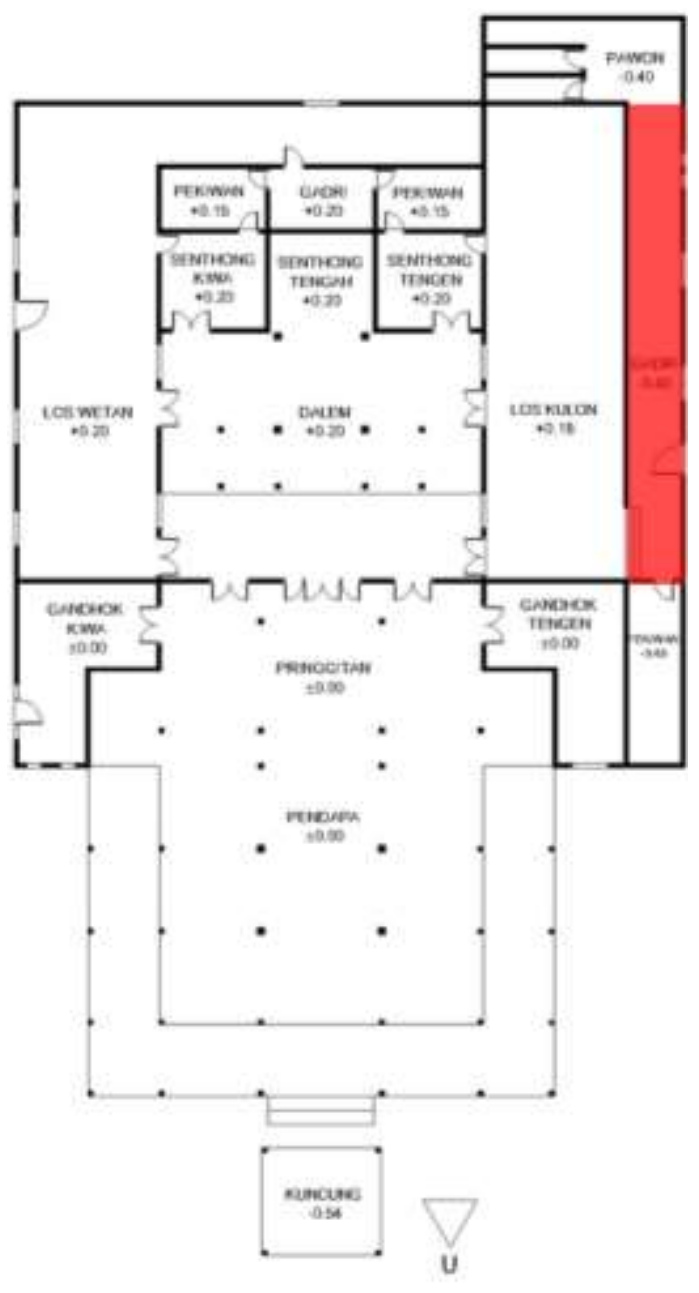

Legend

Gadri (semi-private zone)

Figure 6. Zoning of changed house elements

Gadri is a semi-open room located behind or next to dalem and usually used for dining (Adibowo et al. 2011). Figure 6 shows the gadri in nDalem Puspodiningratan is still used as a dining room but is now enclosed. This means the area still maintains its ability to facilitate harmonious relationships between the house habitants.

The gadri transformations in nDalem Puspodiningratan's are also found in another traditional Joglo house in Omah UGM which is now used as a museum. The gadri was observed not to have changed with the majority of its original layout maintained but its function has changed from being dining to a cultural monument (Pratama, Djalari, and Laksemi 2018). Its use as a showroom also indicates it still maintains relationships among humans. It is important to note that using gadri as a place to gather people preserves the Hamemayu Hayuning Bawana philosophy.

2. Harmonious relationship of human with the environment

The harmonious relationship with the environment is maintained in the unchanged elements of the house despite the spatial transformation. This is evident in the vegetation planted around the site and the maintenance of the existing green area by not constructing pavements. It is important to note that the vegetation in $n$ Dalem Puspodiningratan consists of mostly sapodilla trees.
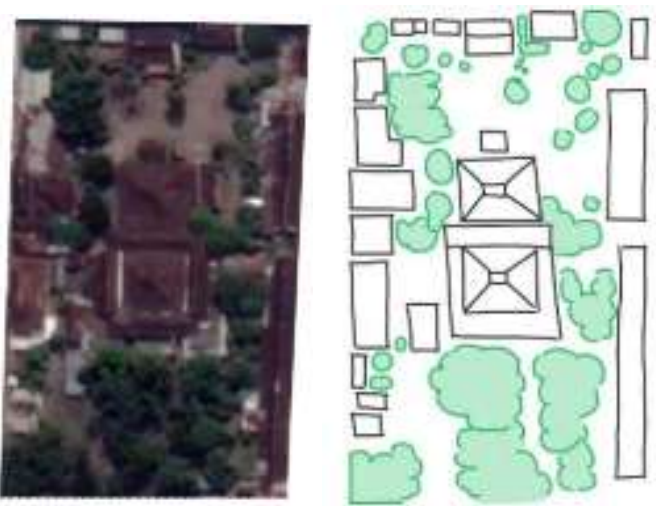

Figure 7. Satellite view

Vegetation affects pollutant concentrations by altering airflows (Stevens et al. 2020) and also assists in storing water in the soil (Lazo et al. 2019; Mobasheri et al. 2019). Moreover, planting trees and not covering the site with pavements allow water absorption and pollutant dispersal. This means a harmonious relationship is maintained with the environment as shown in figure 7.

There are, however, some spatial transformations observed to be disturbing the harmonious relationship with the environment. For example, the floor of the entire building was changed from bligon to ceramics because they are not brittle or soft and this makes their maintenance easier. Bligon is more "breathable" and brittle compared to cement (UNESCO 2007). Meanwhile, the cement plaster used in constructing the ceramic tiles makes soil destruction more apparent compared to the use of bligon which is more "breathable". 

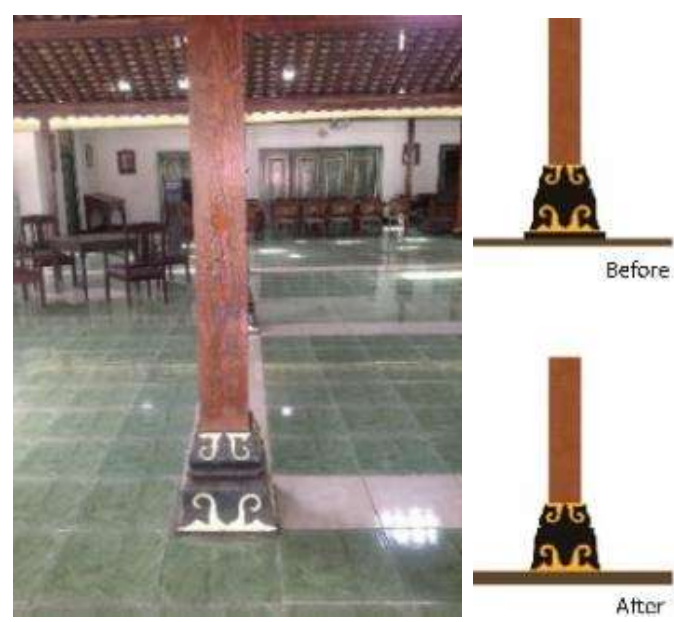

Figure 8. Umpak in pendapa

Source: Nursanty, 2020

Another problem is also caused by installing ceramic tiles especially in the umpak which is a baseboard produced from black natural stone with the bottom pedestal slightly dredged as a shear barrier (UNESCO 2007). Figure 8 shows the umpak was not elevated during the installation of ceramics with its lower part immersed and this makes it less effective in maintaining the stability of the building from earthquakes. This has, therefore, decreased the harmonious relationship with the environment.

The case of the buried umpak base was also reported in $n$ Dalem Purwodiningratan (Pratama, Djalari, and Laksemi 2018). The cement floor covers the base and this makes it less effective to withstand earthquake forces. Burying the umpak base in both cases diminishes the Hamemayu Hayuning Bawana philosophy.

3. Harmonious relationship with God

A harmonious relationship is observed to be maintained with God within the house's unchanged elements and spatial transformations. The aspect of the unchanged elements is indicated by the existence of the tumpang sari which is a horizontal beam arrangement supported by four main pillars as structural columns (Irnawan and Rahayu 2020).

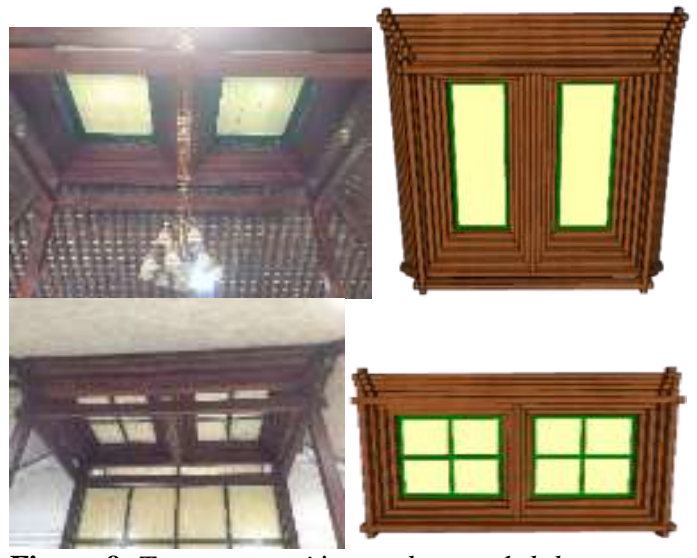

Figure 9. Tumpang sari in pendapa and dalem

Tumpang sari is connected to Islam and figure 9 shows seven-stacked in pendapa and fivestacked in dalem. The five-stack serves as the five-times-shalat reminder, the seven-stack is the representation of God, and the nine-stacked serves as the wali songo and 99 asmaul husna remembrance (Triyanto 2001). This shows the tumpang sari in $n$ Dalem Puspodiningratan has the ability to facilitate a harmonious relationship with God.

The harmonious relationship with God is also observed in the elements undergoing spatial transformations such as the senthong tengah which is a part of dalem and reported to have been sanctioned (UNESCO 2007). Senthong tengah is solely used for heirloom storage and not for other activities but discovered to have been spatially transformed with the elevation made parallel to dalem and the space covered with ceramic tiles.

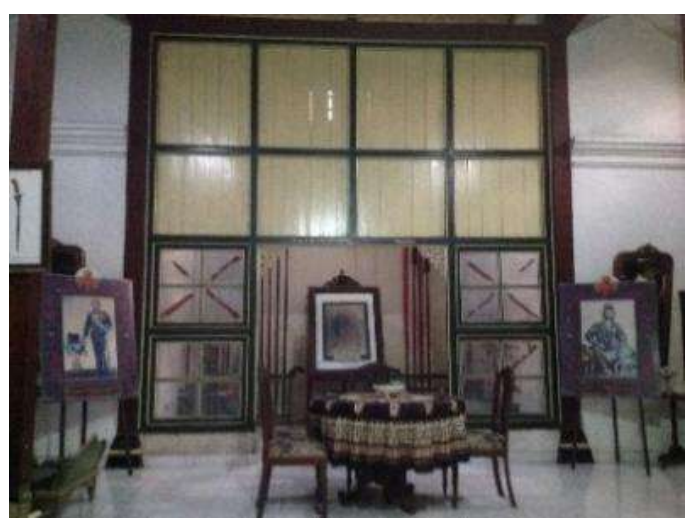



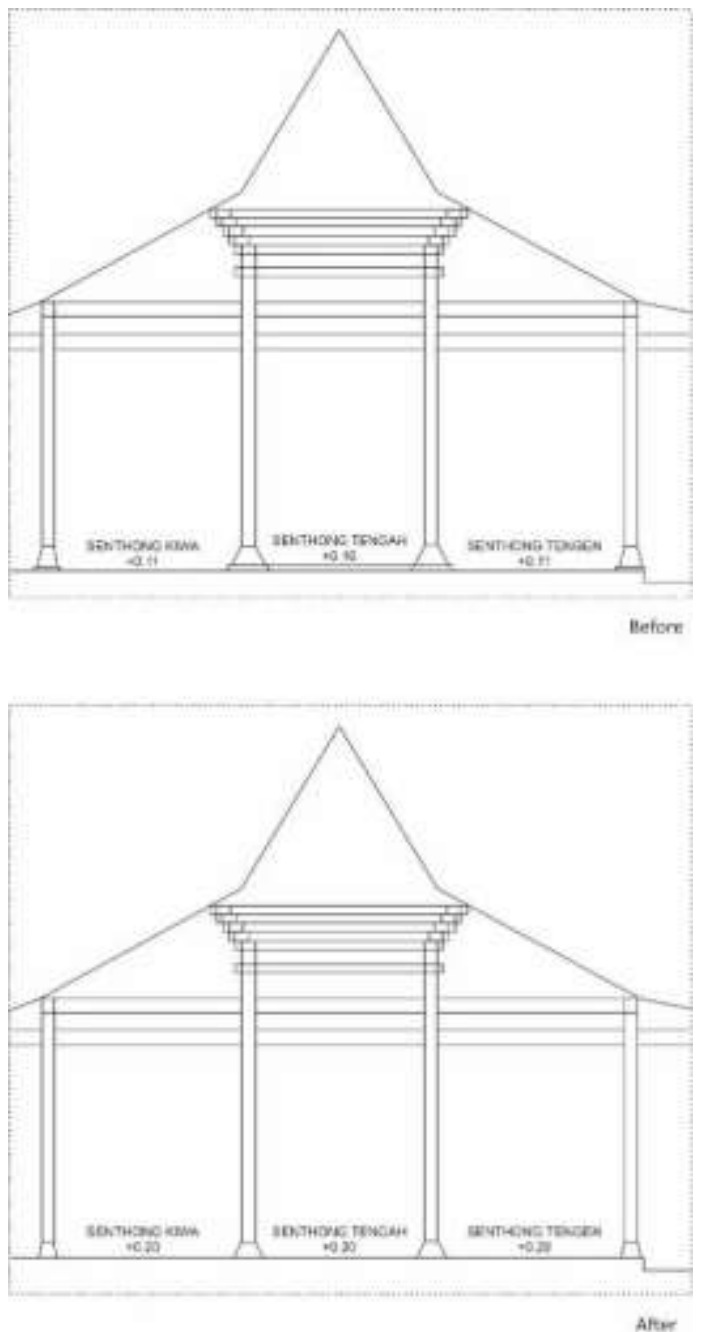

Figure 10. Senthong tengah

Senthong generally has the highest floor height due to its sanctification (UNESCO 2007). It consists of three-lined spaces which include senthong kiwa to store weapons and/or sacred items, senthong tengah sanctified for the fertility goddess Sri, and senthong tengen which is used as a bedroom (Adibowo et al. 2011). Figure 10 shows there are no differences between the floor heights of senthong and dalem in the house. This means its sacred meaning has been reduced spatial-wise especially in senthong tengah even though it is still sanctified and not used for other activities. Therefore, a harmonious relationship is maintained with God.

The changes in the senthong tengah were observed to be different in Omah UGM and nDalem Purwodiningratan. It was discovered to have been transformed from a place of Sri to a cultural monument in both places (Pratama, Djalari, and Laksemi 2018). These transformations led to the loss of its significance as a sanctified place in both places and show the relationship with God is not maintained. This means the functional change of senthong tengah from a sanctified place has the ability to reduce the existence of Hamemayu Hayuning Bawana philosophy.

4. Spatial transformations under the traditional rules of the house

Several patterns are observed from the findings to be emerging with certain spatial transformations discovered to be maintaining the application of Hamemayu Hayuning Bawana in the house while some are reducing the philosophy. The spatial transformation in gadri was found to be aligned with Наmemayu Hayuning Bawana because it does not defy the traditional Joglo house rules of keeping gadri as a room to gather. Meanwhile, the changes in the floor material and height reduce the philosophy due to the violation of the rules which require the floor level should not be below umpak's base and making senthong tengah's floor the same as the surrounding rooms. It is important to note that the house rules are derived from Натеmayu Hayuning Bawana. The house is also a reflection of Javanese cultural values as evident in its form, structure, layout, and decoration (Utomo 2006). This means changes made contrary to the rules do not align with this particular Javanese philosophy. It was, therefore, discovered that the house loses a little bit of its significance as a traditional Joglo house even though it maintains the Hamemayu Hayuning Bawana philosophy at large.

This shows the transformations in traditional Joglo houses have the ability to either preserve or betray the philosophy. Spaces are required to undergo several changes which are probably similar or not to their original intentions in the name of conservation depending on the choices seen as the best solutions for the underlying problems. This means changes occur due to several reasons and this research shows the significant role of functionality in determining the spatial transformations of a house. Meanwhile, the traditional Joglo houses undergo spatial transformations in some cases to survive irrespective of their compliance with the rules. 


\section{Conclusion}

Spatial transformations in nDalem Puspodiningratan were observed to be affecting the Hamemayu Hayuning Bawana philosophy. This is based on the fact that those violating the traditional Joglo house rules are reducing the significance of the philosophy while in line with the rules maintain the philosophy. The transformations in house elements were discovered to be reducing the relationships with the environment but maintain those with humans and God to some extent. The environment is mostly affected due to the application of certain elements that differ from the traditional intentions while the relationships with humans and God are maintained because the original purposes of the spaces are not changed.

The spatial transformation in gadri was observed to be providing a harmonious relationship with humans. This is evident in the changing of the floor in all rooms to ceramic tiles and covering the lower part of the umpak which reduces the harmonious relationship with nature. Moreover, the reduction in the height of the senthong tengah decreases its importance as a sanctified space but maintains its harmonious relationship with God.

There is, however, a need for further research on the spatial transformations in other traditional Joglo houses in relation to the preservation of Hamemayu Hayuning Bawana philosophy. This is necessary to determine the similarities and differences in the preservation of the philosophy across different types of Joglo houses.

\section{References}

Adibowo, Dharma Gupta, Prista Lenora Titisari, and Rizka Nurfitri. 2011. Manual Pelestarian Rumah Adat Kotagede. Jakarta: REKOMPAK.

Brusaporci, Stefano. 2016. "Graphical Analysis 2.0: Digital Representation for Understanding and Communication of Architecture." In 16th International Congress of Architectural Graphic Expression: The Architect, Fromthe Tradition to the XXI Century, 1-11. https://www.researchgate.net/publication/303 843716_Graphical_Analysis_20_Digital_Rep
resentation_for_Understanding_and_Commu nication_of_Architecture.

Bryman, Alan. 1989. Research Methods and Organization Studies. London and New York: Routledge.

Gillham, Bill. 2008. Observation Techniques: Structured to Unstructured. London and New York: Continuum.

Giyarsih, Sri Rum. 2010. "Pola Spasial Transformasi Wilayah Di Koridor Yogyakarta-Surakarta." Forum Geografi 24 (1): $\quad 28-38$. https://doi.org/10.23917/forgeo.v24i1.5013.

Hariwijaya. 2005. Filsafat Jawa: Ajaran Luhur Warisan Leluhur. Yogyakarta: Gelombang Pasang.

Irnawan, Dody, and Silvia Yulita Ratih Setyo Rahayu. 2020. "Perubahan Minat Masyarakat Jawa Terhadap Rumah Model Tradisional Joglo Limasan Menjadi Rumah Modern (Studi Kasus Desa Kemloko, Godong, Grobogan, Jawa Tengah)." KODEPENA 1 (1): 37-45. http://www.jtk.kodepena.org/index.php/jtk/ar ticle/view/7/7.

Jayanti, Nour Eka. 2012. "Transformasi Spasial Koridor Surakarta-Palur Dan SurakartaKartosuro Sebagai Bagian Dari Wilayah Peri Urban Kota Surakarta." Universitas Sebelas Maret.

https://digilib.uns.ac.id/dokumen/detail/2887

5/Transformasi-spasial-koridor-surakartapalur-dan-surakarta-kartosuro-sebagaibagian-dari-wilayah-peri-urban-kotasurakarta.

Kiswari, Maria Damiana Nestri. 2019. "Identifikasi Perubahan Fungsi Ruang Pada Rumah Tinggal Joglo Studi Kasus: Rumah Joglo Di Desa Keji,Kecamatan Muntilan, Kabupaten Magelang, Jawa Tengah.” Jurnal PRAXIS $\quad 2$ (1): 49-65. http://journal.unika.ac.id/index.php/praxis.

Kurnia, Septiawan Santana. 2007. Menulis Ilmiah: Metode Penelitian Kualitatif. Jakarta: Obor Mas.

- 2010. Menulis Ilmiah Metodologi Penelitian Kualitatif. 2nd ed. Jakarta: Yayasan Pustaka Obor Indonesia.

Kusuma, Gianny Angger, and Gerarda Orbita Ida Cahyandari. 2018. "Penilaian Kondisi Fisik Rumah Tradisional Joglo Di Kelurahan Jagalan, Kotagede." Jurnal Arsitektur KOMPOSISI 12 (2): $141-52$. 
http://ojs.uajy.ac.id/index.php/komposisi/arti cle/view/2048/1325.

Lazo, Patricio X., Giovanny M. Mosquera, Jeffrey J. McDonnell, and Patricio Crespo. 2019. "The Role of Vegetation, Soils, and Precipitation on Water Storage and Hydrological Services in Andean Páramo Catchments." Journal of Hydrology 572: 805819.

https://doi.org/10.1016/j.jhydrol.2019.03.050.

Mahendra, Yusril Ihza, and Wisnu Pradoto. 2016. "Transformasi Spasial Di Kawasan Peri Urban Kota Malang." Jurnal Pembangunan Wilayah \& Kota 12 (1): 112 - 127. https://doi.org/10.14710/pwk.v12i1.11462.

Minnatika, Nella. 2019. "Transformasi Spasial Pada Koridor Perkotaan Kedungsepur." Universitas Negeri Semarang. https://lib.unnes.ac.id/34196/.

Mobasheri, Mohammad Reza, Meisam Amani, Mahin Beikpour, and Sahel Mahdavi. 2019. "Soil Moisture Content Estimation Using Water Absorption Bands." Geomatica 73 (3): 63-73. https://doi.org/10.1139/geomat-20180020.

Nugroho, Sigit Sapto, and Elviandri. 2018. "Memayu Hayuning Bawana: Melacak Spiritualitas Transendensi Hukum Pengelolaan Sumber Daya Alam Berbasis Kearifan Masyarakat Jawa." In Hukum Transendental: Pengembangan Dan Penegakan Hukum Di Indonesia, 346-55. Solo: Genta Publishing. http://hdl.handle.net/11617/9709.

Pangesti, Resha Dwiayu. 2017. "Corporate Social Responsibility Dalam Pemikiran Budaya Jawa Berdimensi 'Hamemayu Hayuning Bawana' (Pendekatan Studi Hermeneutika)." Jurnal Riset Akuntansi Dan Bisnis Airlangga 2 (2): 224-38. https://doi.org/10.31093/jraba.v2i2.42.

Pratama, Anugrah, Yusuf Affendi Djalari, and Sangayu Ketut Laksemi. 2018. "PERBANDINGAN RUMAH JOGLO DI JAWA TENGAH DALAM LINGKUP CAGAR BUDAYA (Studi Kasus: Omah UGM Dengan NDalem Purwodiningratan)." Jurnal Seni \& Reka Rancang 1 (1): 83-106.

Prijono, Agus. 2015. "Pemahaman Filosofi Pembangunan Provinsi Daerah Istimewa Yogyakarta Hamemayu Hayuning Bawana, Pelaksanaan Dan Penghargaan Lingkungan Di Pedesaan." In Seminar Nasional Hasil - Hasil Penelitian Dan Pengabdian LPPM
Universitas Muhammadiyah Purwokerto, 277-84. Purwokerto: LPPM Universitas Muhammadiyah PurwokertoPrijono, Agus. https://digilib.ump.ac.id/files/disk1/26/jhptu mp-ump-gdl-agusprijon-1268-1-b13-ag-t.pdf.

Ragin, Charles C. 2004. "Comparative Method." In The Sage Encyclopedia of Social Science Research Methods, 148-151. Sage.

Sari, Ledy Dian, and Asidigisianti Surya Patria. 2020. "Infografis Rumah Joglo Pendopo Agung Mojokerto Sebagai Media Belajar Anak Usia 7-11 Tahun.” Jurnal Seni Rupa 8 (3):

134-144. https://jurnalmahasiswa.unesa.ac.id/index.ph $\mathrm{p} / \mathrm{va} /$ article/view/36002/32022.

Sastrosasmito, Sudaryono. 2020. 'Arsitektur Sebagai Realitas Kemanusiaan (Dari Keseharian Sampai Kesadaran Transendental)'. ARTEKS: Jurnal Teknik Arsitektur 5 (2): $141-42$. https://doi.org/10.30822/arteks.v5i2.531.

Siwalatri, Ni Ketut Ayu. 2014. "Makna Sinkronik Arsitektur Bali Aga Di Kabupaten Buleleng Bali.” Universitas Udayana. http://erepo.unud.ac.id/id/eprint/5711/1/8a9c 726e13e6c618ff59f385f8debc1d.pdf.

Spradley, James P. 1980. Participant Observation. New York, NY: Holt, Rinehart and Winston.

Stevens, C. J., J. N. B. Bell, P. Brimblecombe, C. M. Clark, N. B. Dise, D. Fowler, G. M. Lovett, and P. A. Wolseley. 2020. "The Impact of Air Pollution on Terrestrial Managed and Natural Vegetation." Philosophical Transactions of the Royal Society A 378 (2183): 1-18. https://doi.org/10.1098/rsta.2019.0317.

Subiyantoro, Slamet. 2011. "Rumah Tradisional Joglo Dalam Estetika Tradisi Jawa." Bahasa Dan Seni 39 (1): 68-79. http://journal2.um.ac.id/index.php/jbs/article/ view/143/115.

Susanta, I Nyoman, and I Wayan Wiryawan. 2016. "Konsep Dan Makna Arsitektur Tradisional Bali Dan Aplikasinya Dalam Arsitektur Bali." In Workshop 'Arsitektur Etnik Dan Aplikasinya Dalam Arsitektur Kekinian,' 1-13. https://simdos.unud.ac.id/uploads/file_penelit 
ian_1_dir/96acde4e5d638d5f0c76d5bb24c64 208.pdf.

Triyanto. 2001. Makna Ruang Dan Penataannya Dalam Arsitektur Rumah Kudus. Semarang: Penerbit Kelompok Studi Mekar.

UNESCO. 2007. "Homeowner's Conservation Manual for Kotagede Heritage District." 2007.

http://portal.unesco.org/geography/en/ev.phpURL_ID=9817\&URL_DO=DO_TOPIC\&U RL_SECTION=201.html.

Utomo, Tri Prasetyo. 2006. "Transformasi Nilai Estetika Rumah 'Joglo' Di Kawasan Kotagede Yogyakarta.” Jurnal Ornamen 3 (2): $\quad 60-75 . \quad$ http://repository.isiska.ac.id/2117/.

Wagiran. 2012. "Pengembangan Karakter Berbasis Kearifan Lokal Hamemayu Hayuning Bawana (Identifikasi Nilai-Nilai Karakter Berbasis Budaya)." Jurnal Pendidikan Karakter II (3): 329-39. https://journal.uny.ac.id/index.php/jpka/articl e/view/1249/1050

Wijaya, Riesanti Edie, Novrida Qudsi Lutfillah, and Yenni Mangoting. 2015. "Deconstruction Value Added Statement With Wisdom Java 'Memayu Hayuning Bawana': A Perspective." In Asia Pacific Conference on Accounting and Finance (APCAF 2015). http://repository.ubaya.ac.id/25193/.

\section{Author(s) contribution}

Brigitta Michelle contributed to the research concepts preparation, methodologies, investigations, data analysis, visualization, articles drafting and revisions.

Yohanes Djarot Purbadi contribute to the research concepts preparation and literature reviews, data analysis, of article drafts preparation and validation. 